\title{
Chemical Structure and Microstructure Characterization of Ladder-Like Silsesquioxanes Derived Porous Silicon Oxycarbide Materials
}

\author{
Jakub Marchewka *(D), Piotr Jeleń (D), Izabela Rutkowska, Patryk Bezkosty and Maciej Sitarz (D) \\ Faculty of Material Science and Ceramics, AGH University of Science and Technology, al. Mickiewicza 30, \\ 30-059 Kraków, Poland; pjelen@agh.edu.pl (P.J.); irutkowska@agh.edu.pl (I.R.); bezkosty@agh.edu.pl (P.B.); \\ msitarz@agh.edu.pl (M.S.) \\ * Correspondence: jmar@agh.edu.pl
}

Citation: Marchewka, J.; Jeleń, P.; Rutkowska, I.; Bezkosty, P.; Sitarz, M. Chemical Structure and

Microstructure Characterization of Ladder-Like Silsesquioxanes Derived Porous Silicon Oxycarbide Materials. Materials 2021, 14, 1340. https:// doi.org/10.3390/ma14061340

Academic Editors: Huisu Chen and Pavel Diko

Received: 27 January 2021

Accepted: 8 March 2021

Published: 10 March 2021

Publisher's Note: MDPI stays neutral with regard to jurisdictional claims in published maps and institutional affiliations.

Copyright: (C) 2021 by the authors Licensee MDPI, Basel, Switzerland. This article is an open access article distributed under the terms and conditions of the Creative Commons Attribution (CC BY) license (https:// creativecommons.org/licenses/by/ $4.0 /)$.

\begin{abstract}
The aim of this work was to synthesize porous ceramic materials from the SiOC system by the sol-gel method and the subsequent pyrolysis. The usage of two types of precursors (siloxanes) was determined by $\mathrm{Si} / \mathrm{C}$ ratio in starting materials. It allows us to control the size of the pores and specific surface area, which are crucial for the potential applications of the final product after thermal processing. Methyltrimethoxysilane and dimethyldiethoxysilane were mixed in three different molar ratios: 4:1, 2:1, and 1:1 to emphasize $\mathrm{Si} / \mathrm{C}$ ratio impact on silicon oxycarbide glasses properties. Structure and microstructure were examined both for xerogels and obtained silicon oxycarbide materials. Brunauer-Emmett-Teller (BET) analysis was performed to confirm that obtained materials are porous and $\mathrm{Si} / \mathrm{C}$ ratio in siloxanes precursors affects porosity and specific surface area. This kind of porous ceramics could be potentially applied as gas sensors in high temperatures, catalyst supports, filters, adsorbents, or advanced drug delivery systems.
\end{abstract}

Keywords: silsesquioxanes; silicon oxycarbide; porous ceramics; sol-gel synthesis

\section{Introduction}

Porous ceramic materials have been successfully used in many industries, including thermal insulation materials [1,2], filters [3], membranes [4], adsorbents [5], catalyst supports [6], and materials for medicine [7]. The huge variety of methods of their preparation allows us to control the most important properties, such as permeability, specific surface area, shape, and size of the pores in a wide range. One of the traditional and simplest methods of obtaining porous ceramics is sintering of ceramic powders. Generally this method is used to receive materials with low porosity in the order of 30\% [8]. More sophisticated and modern methods, such as additive manufacturing and other rapid prototyping techniques, enable to obtain materials with precisely defined porosity and designed shape $[9,10]$.

In an unconventional way, porous ceramics can also be received from preceramic polymers as starting precursors. This type of materials is classified as a Polymer Derived Ceramics (PDCs). The first mention of them comes from the 1960s, when Ainger and Herbert [11], and Chantrell and Popper [12], submitted the receiving of nonoxide ceramics from molecular precursors. Nowadays, the most known and investigated classes of PDCs are $\mathrm{Si}_{3} \mathrm{~N}_{4}, \mathrm{SiC}, \mathrm{SiCN}, \mathrm{SiOC}$, and also a quaternary system with the addition of boron or aluminum to $\mathrm{SiCN}$ and $\mathrm{SiOC}$ systems [13]. Among them, silicon oxycarbide glass (from SiOC system) seems to be particularly interesting due to its high chemical and thermal resistance [14,15] and ability to introduce porosity in a relatively easy way [16].

Silicon oxycarbide (SiOC) glasses are materials with an amorphous silica structure, in which two oxygen anions $\mathrm{O}^{2-}$ are replaced by one carbon anion $\mathrm{C}^{4-}$. Such anionic substitution in silica glass network leads to a local increase in the density of bonds, so that mechanical strength and thermal stability (up to $150{ }^{\circ} \mathrm{C}$ ) are significantly improved [17-19]. 
Theoretically, all the basic properties of SiOC glasses will be ameliorated as the amount of carbon incorporated into the glass structure increases. However, silica glass structure can accept only a limited amount of carbon anions and the rest occur as a free carbon phase in practice [20]. The consequence is deterioration of some physicochemical properties and black color of the received materials (hence the SiOC glasses are interchangeably known as black glasses) [21,22]. Researches on the black glasses were generally focused on solid materials or coatings for high-temperature applications [23,24], bioactive components [25,26], and some electronic applications (e.g., microelectromechanical systems) [27]. Nowadays, porous SiOC glasses are gaining increasingly importance because of their possible applications as anode material in Li-ion intercalation batteries [28], catalyst supports [29], sorbents [30], gas sensors [31], and drug delivery systems [32]. Worth mentioning is fact that such materials are characterized with properties comparable to aluminum oxide, like high porosity, which is related to high surface area, chemical inertness in aggressive environments, and thermal stability. One of the main innovative applications of $\mathrm{Al}_{2} \mathrm{O}_{3}$ is in the field of catalysis as catalyst support, therefore $\mathrm{SiOC}$ materials may be a perfect alternative in this application $[33,34]$.

Silicon oxycarbide materials have been received over the decades by numerous methods: Chemical vapor deposition (CVD) and its modifications [35,36], magnetron sputtering [37], spark plasma sintering (SPS) [38], and the others [13]. These methods are quite complicated and also require expensive laboratory equipment. On the other hand, a simple and relatively effective route to obtain black glasses is to use the sol-gel method with appropriate polymeric precursors which contain $\mathrm{Si}-\mathrm{C}$ bonds $[39,40]$. These bonds are responsible for durability both of xerogels and glass, which is obtained after thermal processing [41]. It is during the pyrolysis process when the pores are formed, and their size and shape depend mainly on precursors and the type of solvent used in synthesis [42-44].

The aim of this work was to obtain silicon oxycarbide materials with a high surface area. The amorphous materials from SiOC system were received from ladder-like polysilsesquioxanes. Moreover, the study evaluated the impact of $\mathrm{Si} / \mathrm{C}$ ratio of starting precursors as the key properties for porous ceramics. In addition, the potential applications for these materials, such as high-temperature gas sensors or highly efficient adsorbents and catalyst supports, were also indicated.

\section{Materials and Methods}

Preparation of polysiloxane sol-Methyltriethoxysilane (MTES, $\geq 98 \%$, Sigma-Aldrich, Saint Louis, MO, USA) and dimethyldiethoxysilane (DMDES, $\geq 97 \%$, Sigma-Aldrich) were used as the substrates for sol-gel synthesis of ladder-like polysilsesquioxanes according to our procedure described previously [38]. It is known [45] that during the synthesis of ladder-like polysilsesquioxanes, MTES and DMDES allow the introduction of T (three oxide ions and one carbon ion by one silicon ion) and $\mathrm{D}$ (two oxide ions and two carbon ion by one silicon ion) structural units, respectively, into the final product. Briefly, both reagents were mixed in 1:1, 2:1, and 4:1 volume ratio using ethanol (99.8\%, Avantor Performance Materials, Gliwice, Poland) as a solvent. Then, the mixture was hydrolyzed with diluted $(\mathrm{pH}=4.5) 1 \mathrm{M}$ hydrochloric acid (Avantor Performance Materials). After subsequent polycondensation, three types of sol solutions (T:D 1:1, T:D 2:1, and T:D 4:1, respectively) were obtained.

Preparation of silicon oxycarbide materials-T:D 1:1, T:D 2:1, and T:D 4:1 sols were poured into Petri dishes and dried at $70{ }^{\circ} \mathrm{C}$ for 7 days. Obtained xerogels were described as S1, S2, and S3 samples, respectively. Then, they were pyrolyzed in a nitrogen atmosphere (99.999\%, Air Liquide, Kraków, Poland) using the procedure including the following stages-heating at the rate of $5{ }^{\circ} \mathrm{C} / \mathrm{min}$, holding at $800{ }^{\circ} \mathrm{C}$ for $30 \mathrm{~min}$, and subsequent cooling to the room temperature inside the furnace. The inert gas was applied to avoid the oxidation of the material and the loss of carbon from the product structure. Samples S1-S3 after the pyrolysis were described as S4-S6, respectively. Samples were obtained as loose bulk materials. 
X-Ray Diffraction (XRD) -X-Ray diffractograms of S1-S6 samples were obtained with X'Pert Pro (Malvern Panalytical, Malvern, UK) diffractometer. CuK $\alpha 1$ radiation was applied in Bragg-Brentano geometry in the $2 \theta$ range from 10 to $90^{\circ}$ and at the step of $0.008^{\circ}$ using Debye-Scherrer-Hull (DSH) method.

Fourier-transformed Infrared spectroscopy (FT-IR) — the structure of S1-S6 samples was analyzed by FT-IR spectroscopy using Vertex 70v (Bruker, Billerica, MA, USA) spectrometer and standard $\mathrm{KBr}$ pellet technique. The measurements in the absorbance mode were performed in the range from 400 to $4000 \mathrm{~cm}^{-1}$, at the resolution of $4 \mathrm{~cm}^{-1}$, and collecting 128 scans.

Magic Angle Spinning Nuclear Magnetic Resonance (MAS NMR)—MAS-NMR spectra for S2 and S4 samples were recorded on Avance $500 \mathrm{MHz}$ (Bruker) spectrometer with a probe size of $4 \mathrm{~mm}$. The parameters of the analysis were as follows: Spinning speed of $15 \mathrm{kHz}, 3000$ scans with a total accumulation time of $100 \mathrm{~min}$ for ${ }^{13} \mathrm{C}$ MAS NMR and spinning speed of $5 \mathrm{kHz}$, and 4500 scans with a total accumulation time of $150 \mathrm{~min}$ for ${ }^{29} \mathrm{Si}$ MAS NMR. Spectral deconvolution was conducted based on Levenberg-Marquardt algorithm using Bruker OPUS 7.2 software [46].

Brunauer-Emmett-Teller (BET) surface area analysis—-the specific surface area and the pore size distribution of S4-S6 samples were evaluated based on BET adsorption isotherms for nitrogen using ASAP 2010 system (Micromeritics Instrument Corporation, Norcross, GA, USA). The samples were degassed at $300^{\circ} \mathrm{C}$ for $72 \mathrm{~h}$ before the measurements.

\section{Results and Discussion}

The basic structural units of silsesquioxane ladders are $T$ units [47]. On the other hand, $\mathrm{D}$ units most often form oligo- or polysilsesquioxanes [47]. Their application in a specific molar ratio and with the appropriate conditions of the polycondensation reaction makes it possible to strictly define their structure. Therefore, after their subsequent pyrolysis silicon oxycarbide materials with a controlled amount of Si-C bonds could be obtained. Depending on the conditions of the thermal processing during the whole procedure (drying, pyrolysis) the porous microstructure of the final product is generated. In this work, these parameters were determined based on our previous results $[20,40,48]$. However, to the best of our knowledge, porous $\mathrm{SiOC}$ materials obtained from ladder-like silsesquioxanes have not yet been investigated. Therefore, it was decided to mix both reagents in three different proportions: 1:1, 2:1, and 4:1, to examine the influence of $\mathrm{Si} / \mathrm{C}$ ratio in starting materials on structural and microstructural characterization and most important properties for final porous products.

X-Ray diffraction examination was conducted for all samples, i.e., the xerogels and the silicon oxycarbide materials (Figure 1). For the S1-S3 samples before thermal processing, there are no characteristic crystalline peaks observed, therefore their structure could be considered as amorphous. Additionally, two regions of background rise, the so called amorphous "halo", are observed in 2Theta ranges $8-12^{\circ}$ and $20-28^{\circ}$. Such an observation is typical for ladder like-structures. The first reflection is due to the limited degree of order of the intermolecular chain distance, while the second one can be the result of the distance between the ladder structure $[45,48]$. Samples after thermal processing at $800{ }^{\circ} \mathrm{C}$ similarly do not show any crystalline peaks, which classify their structure as amorphous. There is one broad amorphous "halo" at range $18-24^{\circ} 2 \mathrm{Theta}$, which is characteristic for SiOC materials. 


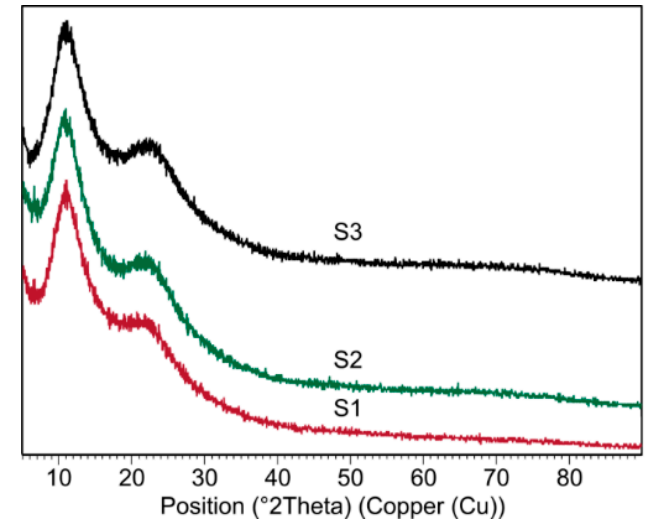

(a)

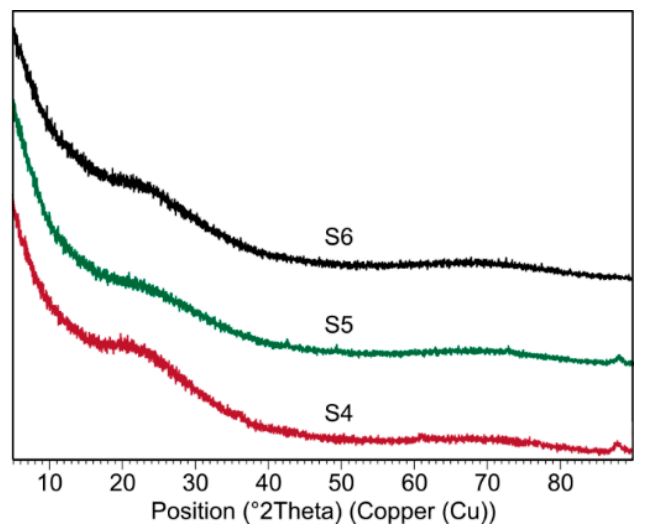

(b)

Figure 1. XRD diffraction patterns of (a) the xerogels (S1-S3 samples) and (b) the silicon oxycarbide materials (S4-S6 samples).

The FT-IR spectra of all xerogels (samples S1-S3) are very similar (Figure 2a). The two most intense bands observed at about $1030 \mathrm{~cm}^{-1}$ and around $1090-1120 \mathrm{~cm}^{-1}$ are specific for polysilsesquioxanes ladder-like structure and they are attributed to the stretching vibrations of Si-O-Si bridges and rings, respectively [20,49]. Furthermore, the weak band at about $570 \mathrm{~cm}^{-1}$ could be assigned to the stretching vibrations of four-fold Si-O-Si rings typical for ladder-like structures and the noticeable one at about $440 \mathrm{~cm}^{-1}$ to the Si-O bending vibration $[20,40,50]$. Numbers of bands visible in the spectra are associated with the presence of $\mathrm{Si}_{-} \mathrm{CH}_{3}$ groups in the obtained polysilsesquioxanes. These visible between 700 and $800 \mathrm{~cm}^{-1}$ are responsible for the stretching vibrations of $\mathrm{Si}-\mathrm{C}$ bonds, whereas the ones at about $1270 \mathrm{~cm}^{-1}$ and $1410 \mathrm{~cm}^{-1}$ for the stretching vibrations and at about $850 \mathrm{~cm}^{-1}$ for the bending vibrations of C-H bonds. The two bands at about $2920 \mathrm{~cm}^{-1}$ and $2970 \mathrm{~cm}^{-1}$ are typical for the stretching vibrations of $\mathrm{C}-\mathrm{H}$ bonds [50,51]. The broad band at about $3440 \mathrm{~cm}^{-1}$ and the weak one at $1627 \mathrm{~cm}^{-1}$ are attributed to the stretching and bending modes of $\mathrm{O}-\mathrm{H}$ bond in water. This indicates the presence of water molecules absorbed in S2 and S3 samples and could be associated with their higher porosity compared to S1 sample.

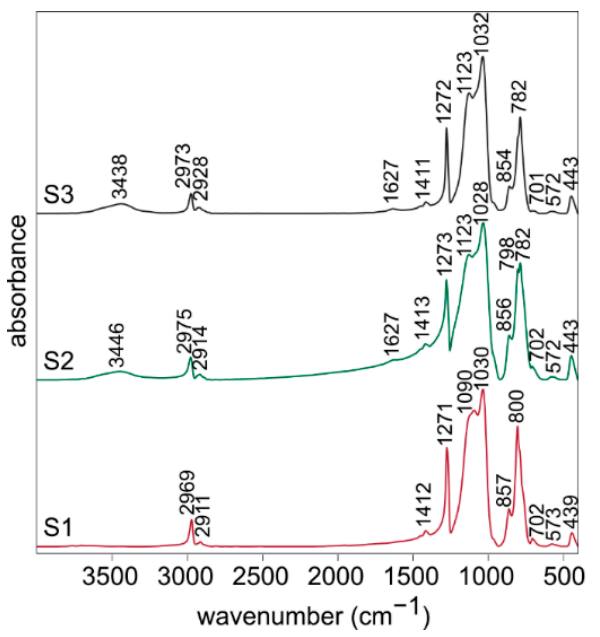

(a)

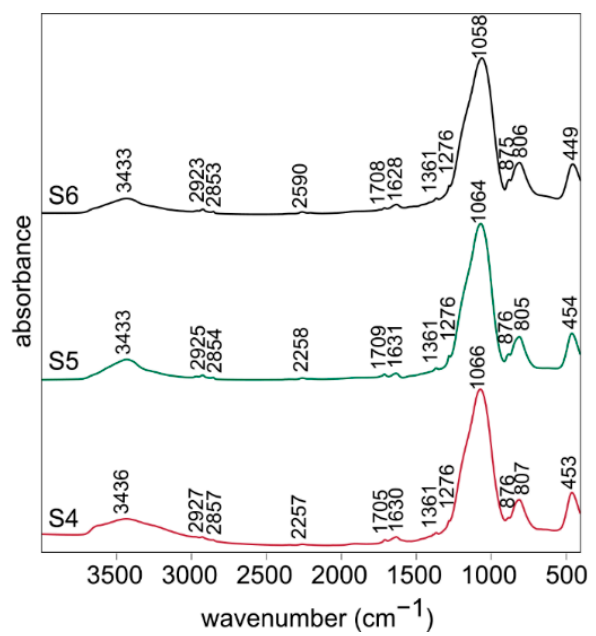

(b)

Figure 2. FT-IR spectra for (a) the xerogels (S1-S3 samples) and (b) the silicon oxycarbide materials (S4-S6 samples).

The FT-IR spectra of all obtained silicon oxycarbide materials (samples S4-S6) also closely resemble each other, but they are much different compared to the ones for the xerogels (Figure $2 b$ ). This shows that the significant changes of the structure occurred 
during the pyrolysis. The most intense band at about $1060 \mathrm{~cm}^{-1}$ is attributed to the stretching vibrations in Si-O-Si structure. Then, the next significant ones, visible at about 805 $\mathrm{cm}^{-1}$ and $450 \mathrm{~cm}^{-1}$, are assigned to the Si-O-Si stretching and O-Si-O bending vibrations. The bands at about $2260 \mathrm{~cm}^{-1}$ for the stretching vibration and about $875 \mathrm{~cm}^{-1}$ for the bending vibration could be assigned to the reactive $\mathrm{Si}-\mathrm{H}$ bond $[49,52]$. Their presence may be beneficial in case of the potential applications of the materials in catalysis. Moreover, the very weak band at about $1710 \mathrm{~cm}^{-1}$ could be explained as the stretching vibration of $\mathrm{C}=\mathrm{O}$ bond in the small share of oxidized free carbon phase [20]. A few very weak bands at about $2925 \mathrm{~cm}^{-1}, 2855 \mathrm{~cm}^{-1}$, as well as at $1361 \mathrm{~cm}^{-1}$ and $1276 \mathrm{~cm}^{-1}$ are associated with the stretching vibrations of $\mathrm{C}-\mathrm{H}$ bonds in the polysilsesquioxanes. This indicates the presence of the organic phase remnants in the material after the pyrolysis. It is possible that they will be removed with the application of the higher temperature in the process. As it was mentioned before, $3440 \mathrm{~cm}^{-1}$ and $1627 \mathrm{~cm}^{-1}$ bands are specific for $\mathrm{O}-\mathrm{H}$ bond in water. They are more intense compared to these observed in the spectra for xerogels. This may suggest that the porosity of the material after the pyrolysis is significantly higher.

Detailed FT-IR spectra analysis for the xerogels and silicon oxycarbide materials are presented in Tables 1 and 2.

${ }^{29} \mathrm{Si}$ and ${ }^{13} \mathrm{C}$ MAS NMR experiments were performed in one series of the samples based on T:D 2:1 polysilsesquioxanes sol, i.e., S2 xerogel and S4 silicon oxycarbide material. Spectral deconvolution was performed to identify the individual signals. Nine of them grouped in two ranges between 0 and $-25 \mathrm{ppm}$ as well as between -50 and $-70 \mathrm{ppm}$ were distinguished in ${ }^{29}$ Si MAS NMR spectrum for S2 sample (Figure 3a). They were related to silicon atoms in $\mathrm{D}$ and $\mathrm{T}$ structural units, respectively. The evidence of ladder-like polysilsesquioxane structure preparation is given by the signals at -64.7 and $-66.5 \mathrm{ppm}[50,53,54]$. The presence of - $\mathrm{OSi}\left(\mathrm{CH}_{3}\right)_{2}$ - units in the xerogel structure is proven by the signal at $-21.1 \mathrm{ppm}$, whereas terminal $-\mathrm{OSi}\left(\mathrm{CH}_{3}\right)_{2} \mathrm{OH}$ groups are assigned to the signal at $-11.7 \mathrm{ppm}[50,55]$. Moreover, the signals at $-7.6,-18.3$, and $-19.2 \mathrm{ppm}$ may be associated with trimeric and tetrameric polycyclosiloxanes derived from DMDES molecules which did not generate ladder-like structure [50,55]. Two signals at -55.5 and $-57.0 \mathrm{ppm}$ derived from open-chain oligomers. ${ }^{13} \mathrm{C}$ MAS NMR spectrum for S2 sample (Figure $3 \mathrm{~b}$ ) was collected to get a complementary information about the xerogel structure. Intensive signals at -3.2 and $0.3 \mathrm{ppm}$ are related to carbon atoms in $\mathrm{Si}_{-} \mathrm{CH}_{3}$ groups of $\mathrm{D}$ and $\mathrm{T}$ structural units, respectively, which confirms the preservation of $\mathrm{Si}-\mathrm{CH}$ bonds in the xerogel $[50,56]$. Besides, weak signals at 17.8 and $57.7 \mathrm{ppm}$ could be assigned to -SiOEt groups in the remaining unreacted molecules of the substrates, most probably D units, as seen in Figure $3 \mathrm{a}^{29} \mathrm{Si}$ NMR [57].

${ }^{29} \mathrm{Si}$ MAS NMR spectrum for S4 sample (Figure 4a) indicates its complex structure. The most intense signal at $-64.1 \mathrm{ppm}$ is assigned to silicon atoms in $\left[\mathrm{SiO}_{3} \mathrm{C}\right]$ ( $\mathrm{T}$ structural units). Other signals could be associated as follows: $3.0 \mathrm{ppm}$ to [ $\left.\mathrm{SiOC}_{3}\right]$ (M structural units), $-36.0 \mathrm{ppm}$ to $\left[\mathrm{SiO}_{2} \mathrm{C}_{2}\right](\mathrm{D}),-100.7 \mathrm{ppm}$ to $\left[\mathrm{SiO}_{3} \mathrm{OH}\right]\left(\mathrm{Q}^{3}\right),-108.8 \mathrm{ppm}$ to $\left[\mathrm{SiO}_{4}\right]\left(\mathrm{Q}^{4}\right)$, and $-11.1 \mathrm{ppm}$ to $\left[\mathrm{SiC}_{4}\right](\mathrm{X})[54,57]$. They are typical to the structure of silicon oxycarbide, and therefore this confirms the preparation of this material during the pyrolysis. Furthermore, the signal at $-24.3 \mathrm{ppm}$ may be related to $\left[\mathrm{HSiO}_{3}\right]\left(\mathrm{D}^{\mathrm{H}}\right.$ structural units) [58]. This is consistent with FT-IR analysis, which shows the presence of $\mathrm{Si}-\mathrm{H}$ bonds in the material. Based on the integral intensities obtained during the mathematical deconvolution of the ${ }^{29} \mathrm{Si}$ NMR spectrum, the percentages of individual structural units were calculated (Table 3 ). The analysis shows that $\left[\mathrm{SiO}_{3} \mathrm{C}\right]$ ( $\mathrm{T}$ structural units) is the dominant phase, followed by $\left[\mathrm{SiO}_{2} \mathrm{C}_{2}\right]$ (D) phase. Additionally, the ratio of T units to $\mathrm{D}$ units equals $2.2: 1$, which is almost the starting value/desired value (2:1). Additional information is given by ${ }^{13} \mathrm{C}$ MAS NMR spectrum for S4 sample (Figure $4 \mathrm{~b}$ ). Signals between 25 and $-5 \mathrm{ppm}$ are typical for carbon bonded to silicon atoms in -Si- $\mathrm{CH}_{\mathrm{X}}$ groups [59]. Therefore, a small amount of them derived from $\mathrm{T}$ and $\mathrm{D}$ structural units remains in the material after the pyrolysis. These signals may be associated this way: -4.3 and $1.7 \mathrm{ppm}$ to $-\mathrm{Si}_{-} \mathrm{CH}_{3}$ groups from $\mathrm{T}$ and $\mathrm{D}$ structural units and $8.4 \mathrm{ppm}$ to $-\mathrm{Si}_{3}-\mathrm{CH}$ groups [40]. Furthermore, the signal at $21.1 \mathrm{ppm}$ is typical 
for [ $\left.\mathrm{SiC}_{4}\right]$ structural units [59]. Other signals at 138.5 and $130.9 \mathrm{ppm}$ may be explained as related to $\mathrm{C}=\mathrm{O}$ bonds in the small share of oxidized free carbon phase, which is also confirmed by FT-IR analysis [60]. The results of ${ }^{13} \mathrm{C}$ MAS NMR experiment are consistent with ${ }^{29} \mathrm{Si}$ MAS NMR, and they also confirm the preparation of silicon oxycarbide during the pyrolysis.

Table 1. Detailed FT-IR spectra analysis for the xerogels (S1-S3 samples), abbreviations explained under the table.

\begin{tabular}{|c|c|c|c|}
\hline \multicolumn{3}{|c|}{ Band Position $\left(\mathrm{cm}^{-1}\right)$ and Characteristics } & \multirow{2}{*}{ Type of the Vibration } \\
\hline S1 & S2 & S3 & \\
\hline- & 3446 br, m & 3438 br, m & $v_{\mathrm{as}}$ and $v_{\mathrm{s}} \mathrm{O}-\mathrm{H}$ in $\mathrm{H}_{2} \mathrm{O}$ \\
\hline $2969 \mathrm{~m}$ & $2975 \mathrm{~m}$ & $2973 \mathrm{~m}$ & $v_{\text {as }}$ of $\mathrm{C}-\mathrm{H}$ in $\mathrm{Si}-\mathrm{CH}_{3}$ \\
\hline $2911 \mathrm{w}$ & $2914 \mathrm{w}$ & $2928 w$ & $v_{\mathrm{s}}$ of $\mathrm{C}-\mathrm{H}$ in $\mathrm{Si}-\mathrm{CH}_{3}$ \\
\hline- & $1627 w$ & $1627 w$ & $\delta_{\mathrm{s}} \mathrm{H}-\mathrm{O}-\mathrm{H}$ in $\mathrm{H}_{2} \mathrm{O}$ \\
\hline $1412 \mathrm{w}$ & $1413 w$ & $1411 \mathrm{w}$ & $v_{\text {as }}$ of $\mathrm{C}-\mathrm{H}$ in $\mathrm{Si}-\mathrm{CH}_{3}$ \\
\hline $1271 \mathrm{~s}$ & $1273 \mathrm{~s}$ & $1272 \mathrm{~s}$ & $v_{\mathrm{S}}$ of $\mathrm{C}-\mathrm{H}$ in $\mathrm{Si}-\mathrm{CH}_{3}$ \\
\hline- & $1123 \mathrm{~s}$ & $1123 \mathrm{~s}$ & $v_{\mathrm{as}}$ of $\mathrm{Si}-\mathrm{O}-\mathrm{Si}$ rings \\
\hline $1090 \mathrm{~s}$ & - & - & $v_{\mathrm{as}}$ of $\mathrm{Si}-\mathrm{O}-\mathrm{Si}$ rings \\
\hline 1030 vs & 1028 vs & 1032 vs & $v_{\text {as }}$ of Si-O-Si bridges \\
\hline $857 \mathrm{~m}$ & $856 \mathrm{~m}$ & $854 \mathrm{~m}$ & $\delta$ of $\mathrm{C}-\mathrm{H}$ in $\mathrm{Si}-\mathrm{CH}_{3}$ \\
\hline $800 \mathrm{~s}$ & $798 \mathrm{~s}$ & - & $v_{\text {as }}$ of $\mathrm{Si}-\mathrm{C}$ in $\mathrm{Si}-\mathrm{CH}_{3}$ \\
\hline- & $782 \mathrm{~s}$ & $782 \mathrm{~s}$ & $v_{\text {as }}$ of $\mathrm{Si}-\mathrm{C}$ in $\mathrm{Si}-\mathrm{CH}_{3}$ \\
\hline $702 \mathrm{w}$ & $702 \mathrm{w}$ & $701 \mathrm{w}$ & $v_{\mathrm{S}}$ of $\mathrm{Si}-\mathrm{C}$ in $\mathrm{Si}-\mathrm{CH}_{3}$ \\
\hline $573 \mathrm{w}$ & $572 \mathrm{w}$ & $572 \mathrm{w}$ & $v_{\mathrm{s}}$ of Si-O-Si rings \\
\hline $439 \mathrm{~m}$ & $443 \mathrm{~m}$ & $443 \mathrm{~m}$ & $\delta$ of O-Si-O \\
\hline
\end{tabular}

Abbreviations: vs-very strong, s-strong, $\mathrm{m}$-medium, $\mathrm{w}$-weak, br-broad, $v$-stretching vibration, $\delta$ bending vibration (subscripts: $\mathrm{s}$ - symmetric, as-asymmetric).

Table 2. Detailed FT-IR spectra analysis for the silicon oxycarbide materials (S4-S6 samples), abbreviations used as in Table 1.

\begin{tabular}{|c|c|c|c|}
\hline \multicolumn{3}{|c|}{ Band Position $\left(\mathrm{cm}^{-1}\right)$ and Characteristics } & \multirow{2}{*}{ Type of the Vibration } \\
\hline S4 & S5 & S6 & \\
\hline 3436 br, m & 3433 br, m & 3433 br, m & $v_{\mathrm{as}}$ and $v_{\mathrm{s}} \mathrm{O}-\mathrm{H}$ in $\mathrm{H}_{2} \mathrm{O}$ \\
\hline 2927 & 2925 & 2923 & $v_{\text {as }}$ of $\mathrm{C}-\mathrm{H}$ in $\mathrm{Si}-\mathrm{CH}_{3}$ \\
\hline $2857 w$ & $2854 \mathrm{w}$ & $2853 w$ & $v_{\mathrm{S}}$ of $\mathrm{C}-\mathrm{H}$ in $\mathrm{Si}-\mathrm{CH}_{3}$ \\
\hline $2257 w$ & $2258 \mathrm{w}$ & $2590 \mathrm{w}$ & $v \mathrm{Si}-\mathrm{H}$ in $\mathrm{O}-\mathrm{Si}-\mathrm{H}$ \\
\hline $1705 \mathrm{w}$ & $1709 w$ & $1708 \mathrm{w}$ & $v \mathrm{C}=\mathrm{O}$ in oxidized carbon phase \\
\hline $1630 \mathrm{w}$ & $1631 \mathrm{w}$ & $1628 \mathrm{w}$ & $\delta_{\mathrm{s}} \mathrm{H}-\mathrm{O}-\mathrm{H}$ in $\mathrm{H}_{2} \mathrm{O}$ \\
\hline $1361 \mathrm{w}$ & $1361 \mathrm{w}$ & $1361 \mathrm{w}$ & $v_{\mathrm{as}}$ of $\mathrm{C}-\mathrm{H}$ in $\mathrm{Si}-\mathrm{CH}_{3}$ \\
\hline $1276 \mathrm{w}$ & $1276 \mathrm{w}$ & $1276 \mathrm{w}$ & $v_{\mathrm{S}}$ of $\mathrm{C}-\mathrm{H}$ in $\mathrm{Si}-\mathrm{CH}_{3}$ \\
\hline 1066 vs & 1064 vs & 1058 vs & $v_{\mathrm{as}}$ of Si-O-Si bridges \\
\hline $876 \mathrm{w}$ & $876 \mathrm{w}$ & 875 w & $\delta \mathrm{Si}-\mathrm{H}$ in $\mathrm{O}-\mathrm{Si}-\mathrm{H}, v \mathrm{Si}-\mathrm{C}$ \\
\hline $807 \mathrm{~m}$ & $805 \mathrm{~m}$ & $806 \mathrm{~m}$ & $v_{\mathrm{S}}$ of $\mathrm{Si}-\mathrm{O}-\mathrm{Si}$ \\
\hline $453 \mathrm{~m}$ & $454 \mathrm{~m}$ & $449 \mathrm{~m}$ & $\delta$ of $\mathrm{O}-\mathrm{Si}-\mathrm{O}$ \\
\hline
\end{tabular}

Table 3. Calculated percentage share of the structural units in the structure of S4 sample based on ${ }^{29} \mathrm{Si}$ MAS NMR experiment.

\begin{tabular}{ccc}
\hline Structural Unit Type & Chemical Shift $(\mathbf{p p m})$ & \% Share \\
\hline $\mathrm{Q}^{4}\left[\mathrm{SiO}_{4}\right]$ & -108.8 & 4.5 \\
$\mathrm{Q}^{3}\left[\mathrm{SiO}_{3} \mathrm{OH}\right]$ & -100.7 & 12.4 \\
$\mathrm{~T}\left[\mathrm{SiO}_{3} \mathrm{C}\right]$ & -64.1 & 48.7 \\
$\mathrm{D}\left[\mathrm{SiO}_{2} \mathrm{C}_{2}\right]$ & -36.0 & 5.4 \\
$\mathrm{D}^{\mathrm{H}}\left[\mathrm{HSiO}_{3}\right]$ & -24.3 & 16.8 \\
$\mathrm{X}\left[\mathrm{SiC}_{4}\right]$ & -11.1 & 9.3 \\
$\mathrm{M}\left[\mathrm{SiOC}_{3}\right]$ & 3.0 & 2.9 \\
\hline
\end{tabular}




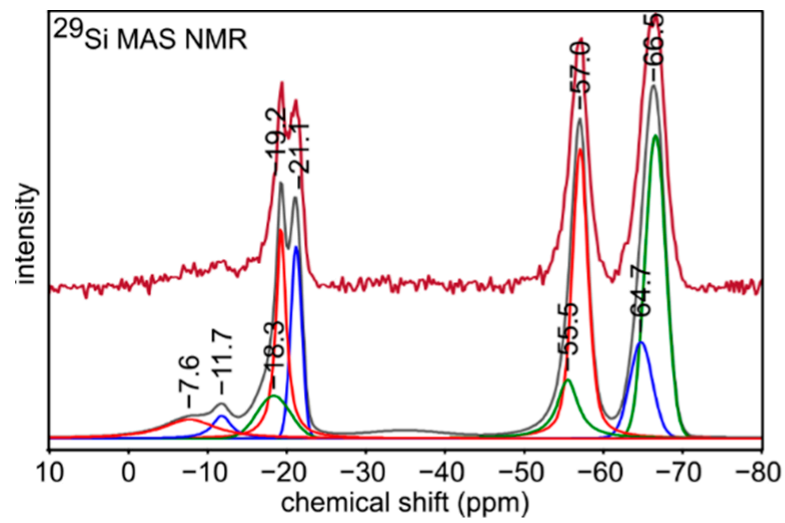

(a)

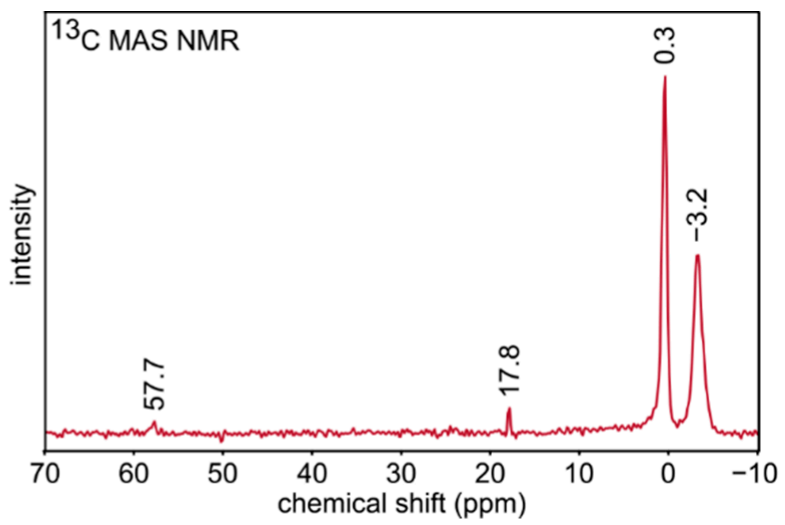

(b)

Figure 3. (a) ${ }^{29} \mathrm{Si}$ and (b) ${ }^{13} \mathrm{C}$ MAS NMR spectra for S2 sample.

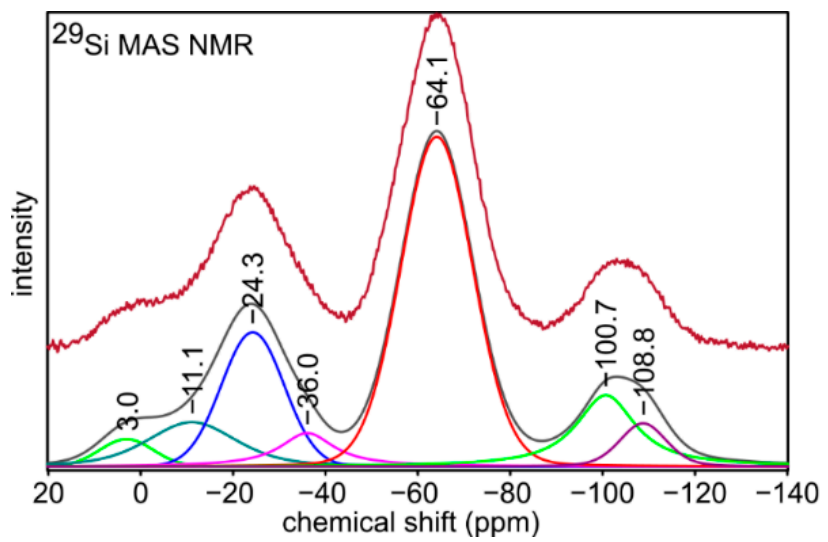

(a)

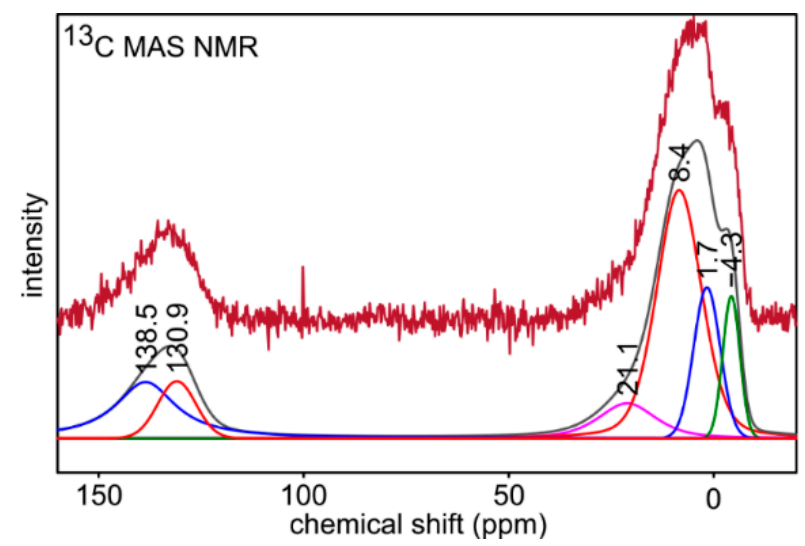

(b)

Figure 4. (a) ${ }^{29} \mathrm{Si}$ and (b) ${ }^{13} \mathrm{C}$ MAS NMR spectra for S4 sample.

Structural analysis indicates that sol-gel synthesis let to prepare ladder-like polysilsesquioxanes build of methyl- and hydroxyl-terminated T and D structural units. A small amount of the remaining ethoxy groups shows that the polycondensation reaction was not fully completed. The presence of $-\mathrm{Si}_{-}-\mathrm{CH}_{3}$ groups in the xerogel structure is crucial for the preparation of silicon oxycarbide. During the pyrolysis Si-C bonds are preserved and therefore carbon atoms are introduced in the silicon oxide structure.

Brunauer-Emmett-Teller (BET) surface area analysis was performed to examine the specific surface area and the pore size distribution of the silicon oxycarbide materials. Two types of nitrogen adsorption-desorption isotherms were obtained for the samples (Figure 5). Type II isotherm was observed for S4 sample, which suggest the multilayer formation during the analysis, and therefore a dominant presence of mesopores in the microstructure. Otherwise, a type I isotherm associated with monolayer formation was noticed for S5 and S6 samples, which indicate a significant share of micropores. The shape of the adsorption branches at the lowest values of relative pressure for these samples suggest a broader range of the pore size distribution including wider micropores and narrow mesopores. Thus, their isotherms may be precisely identified as type $\mathrm{Ib}$. The hysteresis of the isotherms is generally explained as the effect of capillary condensation, which is often associated with the adsorption metastability. Therefore, the thermodynamic equilibrium is established only during the desorption. This may indicate an open-ended geometry of the pores. 


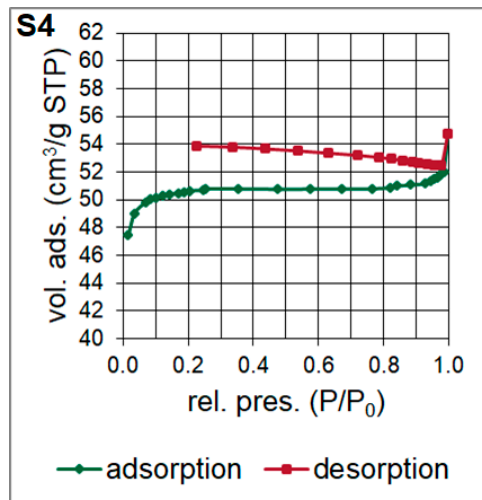

(a)

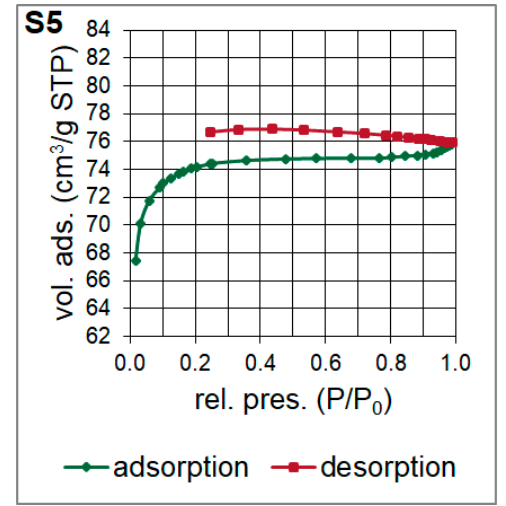

(b)

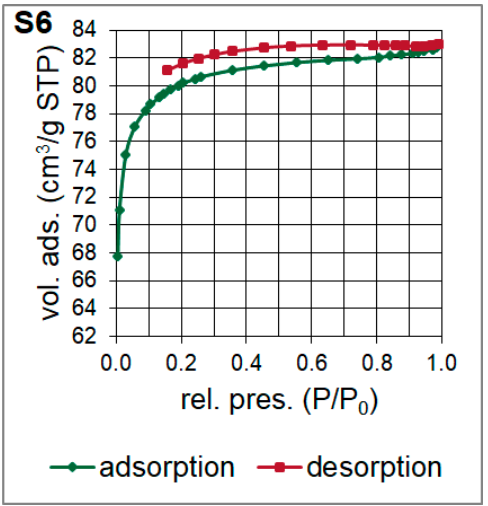

(c)

Figure 5. (a-c) Nitrogen adsorption-desorption isotherms of the silicon oxycarbide materials (S4-S6 samples), abbreviations: vol. ads.-volume adsorbed, rel. pres.-relative pressure.

The result of the surface area and pore volume assessment is shown in Table 4 . The surface area of the S4-S6 samples was determined based on Single Point method as well as BET and Langmuir models. The surface area of the material is increases with the increase of the molar ratio of T:D structural units in the synthesized polysilsesquioxanes sols. It is probably determined by the cross-linking of the initial xerogel. The higher the T:D ratio, the higher the surface area of the obtained materials. During the pyrolysis, gases from bond redistributions $(\mathrm{Si}-\mathrm{C}(\mathrm{H})$ and $\mathrm{Si}-\mathrm{O})$ are released. This leads to the formation of channels/capillaries. Most likely, the free carbon phase is also involved. It is important to underline that the results of Single Point method are mainly used in routine measurements whilst Langmuir model, which is based only on the monolayer formation, often overestimates the results. Therefore, the data obtained with the application of BET model should be the most accurate. The BET surface area for S6 sample was the highest, reaching $268.49 \mathrm{~m}^{2} / \mathrm{g}$. T-Plot method let to assess the micropore area and volume. Both parameters were the lowest for S4 sample and significantly higher for S5 and S6 samples. They were the highest and equal to $236.67 \mathrm{~m}^{2} / \mathrm{g}$ and $0.1099 \mathrm{~cm}^{3} / \mathrm{g}$, respectively, for the latter one. Pore volume and pore area distributions (Figures 6 and 7) were determined based on Barrett-Joyner-Halenda (BJH) analysis. They confirm the mesoporous microstructure for S4 sample and the microporous microstructure with the presence of narrow mesopores for S5 and S6 samples.

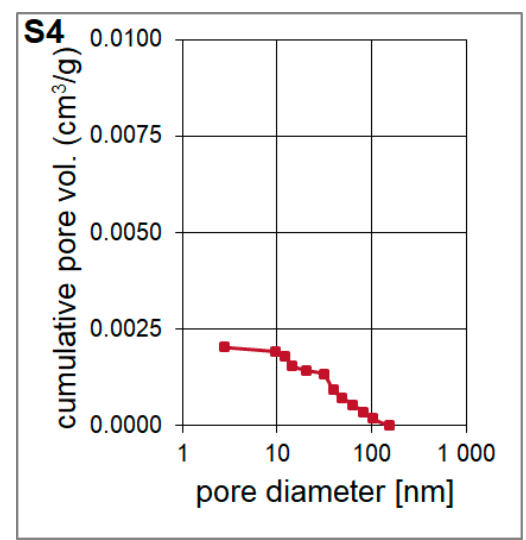

(a)

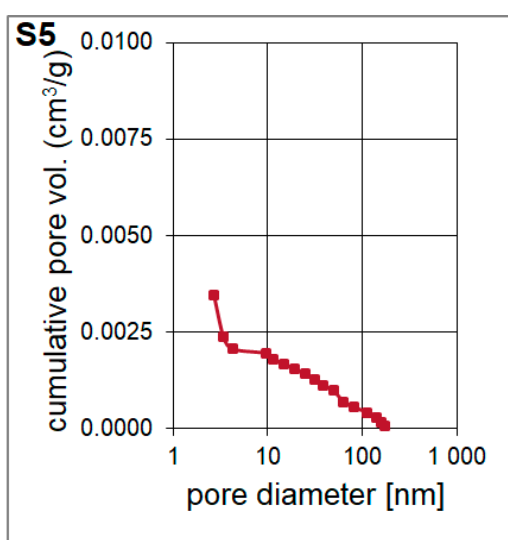

(b)

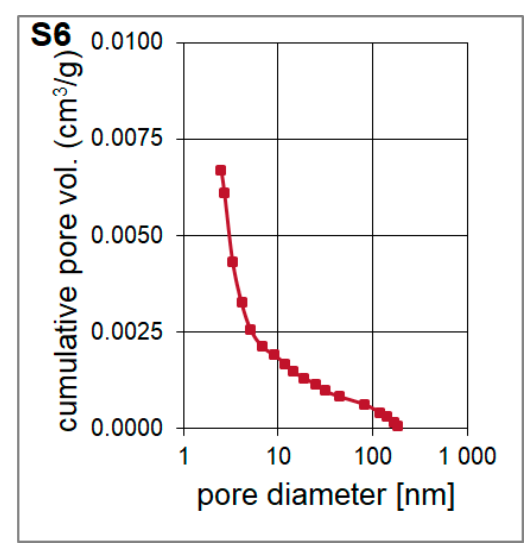

(c)

Figure 6. (a-c) Pore volume of the porous silicon oxycarbide materials, abbreviation: vol.- - volume. 


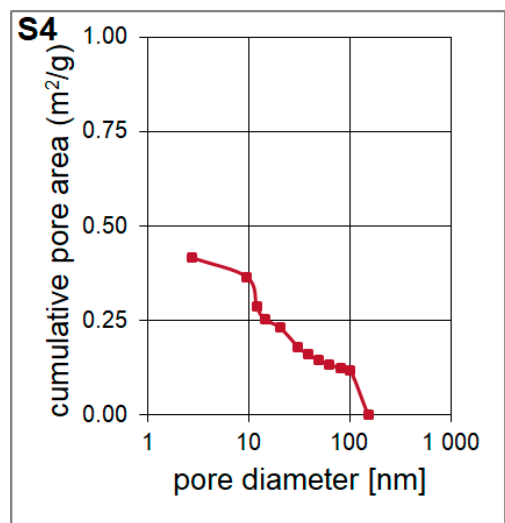

(a)

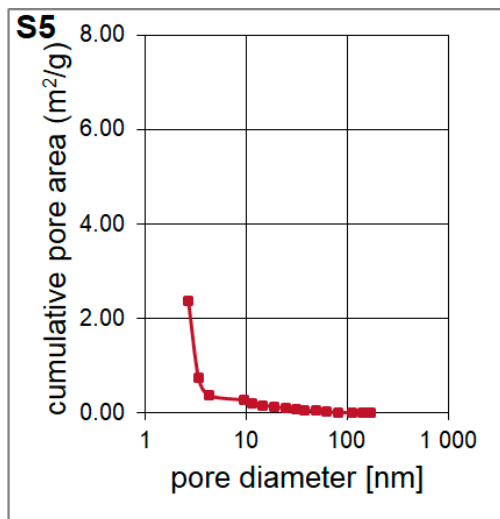

(b)

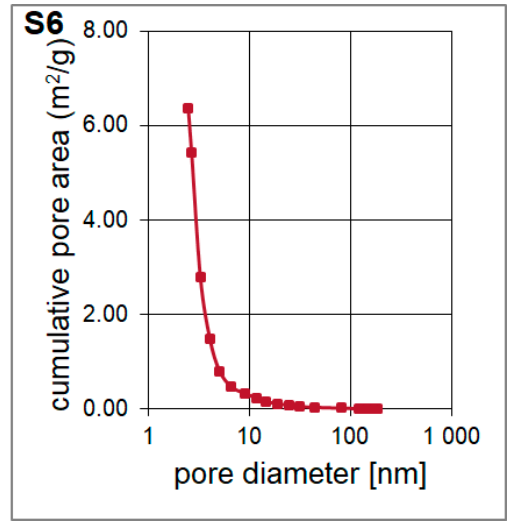

(c)

Figure 7. $(\mathbf{a}-\mathbf{c})$ Pore area of the porous silicon oxycarbide materials.

Table 4. Surface area and pore volume data for samples S4-S6.

\begin{tabular}{cccc}
\hline Parameter & \multicolumn{3}{c}{ Sample } \\
\cline { 2 - 4 } & S4 & S5 & S6 \\
\hline Single Point Surface Area $\left(\mathrm{m}^{2} / \mathrm{g}\right)$ & 175.64 & 257.16 & 277.20 \\
BET Surface Area $\left(\mathrm{m}^{2} / \mathrm{g}\right)$ & 167.41 & 248.31 & 268.49 \\
Langmuir Surface Area $\left(\mathrm{m}^{2} / \mathrm{g}\right)$ & 222.23 & 327.47 & 354.73 \\
t-Plot External Surface Area $\left(\mathrm{m}^{2} / \mathrm{g}\right)$ & 10.05 & 24.39 & 31.83 \\
t-Plot Micropore Area $\left(\mathrm{m}^{2} / \mathrm{g}\right)$ & 157.36 & 223.92 & 236.67 \\
t-Plot Micropore Volume $\left(\mathrm{cm}^{3} / \mathrm{g}\right)$ & 0.0739 & 0.1040 & 0.1099 \\
\hline
\end{tabular}

\section{Conclusions}

Porous ceramic silicon oxycarbide materials were prepared by the sol-gel method and subsequent pyrolysis at $800{ }^{\circ} \mathrm{C}$. Materials were obtained after thermal processing from all synthesized samples. Structural analysis (XRD, FT-IR) enables us to state that samples before the pyrolysis are characterized with the ladder-like structure, while after the pyrolysis, the amorphous structure characteristic for SiOC materials was detected. The ${ }^{29} \mathrm{Si}$ and ${ }^{13} \mathrm{C}$ MAS NMR experiments clearly indicate obtaining SiOC as the final product. The analysis shows that $\left[\mathrm{SiO}_{3} \mathrm{C}\right]$ ( $\mathrm{T}$ structural units) is the dominant phase, followed by the $\left[\mathrm{SiO}_{2} \mathrm{C}_{2}\right]$ (D structural units) phase. BET studies identify mesoporous microstructure for the sample T:D ratio 1:1, whereas microporous microstructure with narrow mesopores is obtained for the samples T:D ratios 2:1 and 4:1, which results in a higher BET surface area. Materials, which are characterized with high surface area (more than $100 \mathrm{~m}^{2} / \mathrm{g}$ ), porous structure, thermal stability, and chemical inertness, can be used as catalyst supports. Prepared materials present similar physicochemical properties to aluminum oxide, which made them a perspective material for catalysts carriers. Other potential applications include high-temperature gas sensors, filters, adsorbents, or advanced drug delivery systems.

Author Contributions: Conceptualization, J.M. and P.J.; methodology, J.M. and P.J.; validation, J.M. and P.J.; formal analysis, J.M. and P.J.; investigation, J.M, P.J., I.R. and P.B.; writing-original draft preparation, J.M, I.R. and P.B.; writing-review and editing, J.M. and P.J.; visualization, J.M, I.R. and P.B.; supervision, M.S.; project administration, M.S.; funding acquisition, M.S. All authors have read and agreed to the published version of the manuscript.

Funding: This research was funded by the National Science Centre, Poland, grant number 2019/35/B/ ST5/00338. The equipment modernization partially supported by Ministry of Science and Higher Education of Poland, grant number 16.16.160.557.

Institutional Review Board Statement: Not applicable. 
Informed Consent Statement: Not applicable.

Data Availability Statement: The data presented in this study are available on request from the corresponding author.

Conflicts of Interest: The authors declare no conflict of interest.

\section{References}

1. Guzman, I.Y. Certain Principles of Formation of Porous Ceramic Structures. Properties and Applications (A Review). Glass Ceram. 2003, 60, 280-283. [CrossRef]

2. Han, L.; Li, F.; Deng, X.; Wang, J.; Zhang, H.; Zhang, S. Foam-gelcasting preparation, microstructure and thermal insulation performance of porous diatomite ceramics with hierarchical pore structures. J. Eur. Ceram. Soc. 2017, 37, 2717-2725. [CrossRef]

3. Salvini, V.R.; Luchini, B.; Aneziris, C.G.; Pandolfelli, V.C. Innovation in ceramic foam filters manufacturing process. Int. J. Appl. Ceram. Technol. 2019, 16, 378-388. [CrossRef]

4. Chen, H.; Zhou, Y.; Su, X.; Cao, S.; Liu, Y.; Gao, D.; An, L. Experimental study of water recovery from flue gas using hollow micro-nano porous ceramic composite membranes. J. Ind. Eng. Chem. 2018, 57, 349-355. [CrossRef]

5. Zhou, L.; Zhou, H.; Hu, Y.; Yan, S.; Yang, J. Adsorption removal of cationic dyes from aqueous solutions using ceramic adsorbents prepared from industrial waste coal gangue. J. Environ. Manag. 2019, 234, 245-252. [CrossRef]

6. Liu, H.; Li, C.; Ren, X.; Liu, K.; Yang, J. Fine platinum nanoparticles supported on a porous ceramic membrane as efficient catalysts for the removal of benzene. Sci. Rep. 2017, 7, 16589. [CrossRef] [PubMed]

7. Motisuke, M.; Carrodeguas, R.G.; Zavaglia, C.A.d.C. Si-tricalcium phosphate cement: Preparation, characterization and bioactivity in SBF. Mater. Res. 2011, 14, 493-498. [CrossRef]

8. Dudina, D.; Bokhonov, B.; Olevsky, E. Fabrication of Porous Materials by Spark Plasma Sintering: A Review. Materials 2019, 12, 541. [CrossRef] [PubMed]

9. Hwa, L.C.; Rajoo, S.; Noor, A.M.; Ahmad, N.; Uday, M.B. Recent advances in 3D printing of porous ceramics: A review. Curr. Opin. Solid State Mater. Sci. 2017, 21, 323-347. [CrossRef]

10. Zhang, G.; Chen, H.; Yang, S.; Guo, Y.; Li, N.; Zhou, H.; Cao, Y. Frozen slurry-based laminated object manufacturing to fabricate porous ceramic with oriented lamellar structure. J. Eur. Ceram. Soc. 2018, 38, 4014-4019. [CrossRef]

11. Ainger, F.W.; Herbert, J.M. The Preparation of Phosphorus-Nitrogen Compounds as Non-Porous Solids. In Special Ceramics; Popper, P., Ed.; Academic Press: New York, NY, USA, 1960; pp. 168-182.

12. Chantrell, P.G.; Popper, P. Inorganic Polymers and Ceramics. In Special Ceramics; Popper, P., Ed.; Academic Press: New York, NY, USA, 1965; pp. 87-103.

13. Colombo, P.; Mera, G.; Riedel, R.; Sorarù, G.D. Polymer-Derived Ceramics: 40 Years of Research and Innovation in Advanced Ceramics. J. Am. Ceram. Soc. 2010, 93, 1805-1837. [CrossRef]

14. Sorarù, G.D.; Modena, S.; Guadagnino, E.; Colombo, P.; Egan, J.; Pantano, C. Chemical Durability of Silicon Oxycarbide Glasses. J. Am. Ceram. Soc. 2002, 85, 1529-1536. [CrossRef]

15. Riedel, R.; Kienzle, A.; Dressler, W.; Ruwisch, L.; Bill, J.; Aldinger, F. A Silicoboron Carbonitride Ceramic Stable to $2000{ }^{\circ} \mathrm{C}$. Nature 1996, 382, 796-798. [CrossRef]

16. Erb, D.; Lu, K. Additive and pyrolysis atmosphere effects on polysiloxane-derived porous SiOC ceramics. J. Eur. Ceram. Soc. 2017, 37, 4547-4557. [CrossRef]

17. Sorarù, G.D. Silicon oxycarbide glasses from gels. J. Sol. Gel Sci. Technol. 1994, 2, 843-848. [CrossRef]

18. Pantano, C.G.; Singh, A.K.; Zhang, H. Silicon oxycarbide glasses. J. Sol. Gel Sci. Technol. 1999, 14, 7-25. [CrossRef]

19. Stabler, C.; Ionescu, E.; Graczyk-Zając, M.; Gonzalo-Juan, I.; Riedel, R. Siliconoxycarbide glasses and glass-ceramics: “AllRounder" materials for advanced structural and functional applications. J. Am. Ceram. Soc. 2018, 101, 4817-4856. [CrossRef]

20. Jeleń, P.; Bik, M.; Nocuń, M.; Gawęda, M.; Długoń, E.; Sitarz, M. Free carbon phase in SiOC glasses derived from ladder-like silsesquioxanes. J. Mol. Struct. 2016, 1126, 172-176. [CrossRef]

21. Blum, Y.D.; MacQueen, D.B.; Kleebe, H.J. Synthesis and characterization of carbon-enriched silicon oxycarbides. J. Eur. Ceram. Soc. 2005, 25, 143-149. [CrossRef]

22. Kleebe, H.J.; Blum, Y.D. SiCO ceramic with high excess free carbon. J. Eur. Ceram. Soc. 2008, 28, 1037-1042. [CrossRef]

23. Bik, M.; Stygar, M.; Jeleń, P.; Dąbrowa, J.; Leśniak, M.; Brylewski, T.; Sitarz, M. Protective-conducting coatings based on black glasses (SiOC) for application in Solid Oxide Fuel Cells. Int. J. Hydrog. Energy. 2017, 42, 27298-27307. [CrossRef]

24. Bik, M.; Gil, A.; Stygar, M.; Dąbrowa, J.; Jeleń, P.; Długoń, E.; Leśniak, M.; Sitarz, M. Studies on the corrosion resistance of SiOC glasses/TiAl alloy system. Intermetallics 2019, 105, 29-38. [CrossRef]

25. Gawęda, M.; Jeleń, P.; Długoń, E.; Wajda, A.; Leśniak, M.; Simka, W.; Sowa, M.; Detsch, R.; Boccaccini, A.R.; Sitarz, M. Bioactive layers based on black glasses on titanium substrates. J. Am. Ceram. Soc. 2018, 101, 590-601. [CrossRef]

26. Arango-Ospina, M.; Xie, F.; Gonzalo-Juan, I.; Riedel, R.; Ionescu, E.; Boccaccini, A.R. Review: Silicon oxycarbide based materials for biomedical applications. Appl. Mater. Today. 2019, 100482. [CrossRef]

27. Harshe, R.; Balan, C.; Riedel, R. Amorphous Si(Al)OC ceramic from polysiloxanes: Bulk ceramic processing, crystallization behavior and applications. J. Eur. Ceram. Soc. 2004, 24, 3471-3482. [CrossRef] 
28. Graczyk-Zając, M.; Vrankovic, D.; Waleska, P.; Hess, C.; Sasikumar, P.V.; Lauterbach, S.; Kleebe, H.J.; Sorarù, G.D. The Li-storage capacity of SiOC glasses with and without mixed silicon oxycarbide bonds. J. Mater. Chem. A 2018, 6, 93-103. [CrossRef]

29. Pan, J.; Shen, W.; Zhao, Y.; Sun, H.; Guo, T.; Cheng, Y.; Zhao, N.; Tang, H.; Yan, X. Difunctional hierarchical porous SiOC composites from silicone resin and rice husk for efficient adsorption and as a catalyst support. Colloids Surf. A Physicochem. Eng. Asp. 2019, 124041. [CrossRef]

30. Pan, J.; Ren, J.; Xie, Y.; Xie, Y.; Wei, X.; Guan, Y.; Yan, X.; Tang, H.; Cheng, X. Porous SiOC composites fabricated from preceramic polymers and wood powders for efficient dye adsorption and removal. Res. Chem. Intermed. 2017, 43, 3813-3832. [CrossRef]

31. Liao, N.; Zheng, B.; Zhang, M.; Xue, W. Numerical approach to evaluate performance of porous $\mathrm{SiC}_{5 / 4} \mathrm{O}_{3 / 2}$ as potential high temperature hydrogen gas sensor. Int. J. Hydrog. Energy. 2019, 44, 26679-26684. [CrossRef]

32. Tamayo, A.; Mazo, M.A.; Ruiz-Caro, R.; Martín-Illana, A.; Bedoya, L.M.; Veiga-Ochoa, M.D.; Rubio, J. Mesoporous silicon oxycarbide materials for controlled drug delivery systems. Chem. Eng. J. 2015, 280, 165-174. [CrossRef]

33. Busca, G. Structural, Surface, and Catalytic Properties of Aluminas. Adv. Catal. 2014, 57, 319-404. [CrossRef]

34. Trueba, M.; Trasatti, S.P. $\gamma$-Alumina as a Support for Catalysts: A Review of Fundamental Aspects. Eur. J. Inorg. Chem. 2005, 17, 3393-3403. [CrossRef]

35. Sitarz, M.; Czosnek, C.; Jeleń, P.; Odziomek, M.; Olejniczak, Z.; Kozanecki, M.; Janik, J.F. SiOC glasses produced from silsesquioxanes by the aerosol-assisted vapor synthesis method. Spectrochim. Acta A Mol. Biomol. Spectrosc. 2013, 112, 440-445. [CrossRef]

36. Yu, S.; Tu, R.; Goto, T. Preparation of SiOC nanocomposite films by laser chemical vapor deposition. J. Eur. Ceram. Soc. 2016, 36, 403-409. [CrossRef]

37. Zare, A.; Su, Q.; Gigax, J.; Shojaee, S.A.; Harriman, T.A.; Nastasi, M.; Shao, L.; Materer, N.F.; Lucca, D.A. Effects of ion irradiation on chemical and mechanical properties of magnetron sputtered amorphous SiOC. Nucl. Instrum. Methods Phys. Res. B. 2019, 446, 10-14. [CrossRef]

38. Mazo, M.A.; Palencia, C.; Nistal, A.; Rubio, F.; Rubio, J.; Oteo, J.L. Dense bulk silicon oxycarbide glasses obtained by spark plasma sintering. J. Eur. Ceram. Soc. 2012, 32, 3369-3378. [CrossRef]

39. Walter, S.; Soraru, G.D.; Bréquel, H.; Enzo, S. Microstructural and mechanical characterization of sol gel-derived Si-O-C glasses. J. Eur. Ceram. Soc. 2002, 22, 2389-2400. [CrossRef]

40. Sitarz, M.; Jastrzębski, W.; Jeleń, P.; Długoń, E.; Gawęda, M. Preparation and structural studies of black glasses based on ladder-like silsesquioxanes. Spectrochim. Acta A Mol. Biomol. Spectrosc. 2014, 132, 884-888. [CrossRef]

41. Gawęda, M.; Długoń, E.; Leśniak, M.; Kurpaska, Ł.; Simka, W.; Sowa, M.; Sitarz, M. The influence of the pyrolysis process on mechanical parameters and tightness of the black glasses layers on titanium substrates. Ceram. Int. 2017, 43, 11345-11353. [CrossRef]

42. Yan, X.; Sahimi, M.; Tsotsis, T.T. Fabrication of high-surface area nanoporous SiOC ceramics using pre-ceramic polymer precursors and a sacrificial template: Precursor effects. Microporous Mesoporous Mater. 2017, 241, 338-345. [CrossRef]

43. Tamayo, A.; Rubio, J.; Rubio, F.; Oteo, J.L.; Riedel, R. Texture and micronanostructure of porous silicon oxycarbide glasses prepared from hybrid materials aged in different solvents. J. Eur. Ceram. Soc. 2011, 31, 1791-1801. [CrossRef]

44. Tamayo, A.; Rubio, F.; Rubio, J.; Oteo, J.L. Surface and structural modification of nanostructured mesoporous silicon oxycarbide glasses obtained from preceramic hybrids aged in $\mathrm{NH}_{4} \mathrm{OH}$. J. Am. Ceram. Soc. 2013, 96, 323-330. [CrossRef]

45. Handke, M.; Sitarz, M.; Długoń, E. Amorphous $\mathrm{SiC}_{\mathrm{x}} \mathrm{O}_{\mathrm{y}}$ coatings from ladder-like polysilsesquioxanes. J. Mol. Struct. 2011, 993, 193-197. [CrossRef]

46. OPUS, version 7.2; FT-IR Spectroscopy Software; Bruker: Billerica, MA, USA.

47. Baney, R.H.; Itoh, M.; Sakakibara, A.; Suzuki, T. Silsesquioxanes. Chem. Rev. 1995, 95, 1409-1430. [CrossRef]

48. Jeleń, P.; Szumera, M.; Gawęda, M.; Długoń, E.; Sitarz, M. Thermal evolution of ladder-like silsesquioxanes during formation of black glasses. J. Therm. Anal. Calorim. 2017, 130, 103-111. [CrossRef]

49. Segatelli, M.G.; Nunes Pires, A.T.; Yoshida, I.V.P. Synthesis and structural characterization of carbon-rich $\mathrm{SiC}_{\mathrm{x}} \mathrm{O}_{\mathrm{y}}$ derived from a Ni-containing hybrid polymer. J. Eur. Ceram. Soc. 2008, 28, 2247-2257. [CrossRef]

50. Handke, M.; Handke, B.; Kowalewska, A.; Jastrzębski, W. New polysilsesquioxane materials of ladder-like structure. J. Mol. Struct. 2009, 924-926, 254-263. [CrossRef]

51. Zhang, L.; Dai, D.; Zhang, R. The synthesis and X-ray diffraction study of the ladder-like polysilsesquioxanes with side-chain ester groups. Polym. Adv. Technol. 1997, 8, 662-665. [CrossRef]

52. Soraru, G.D.; Karakuscu, A.; Boissiere, C.; Babonneau, F. On the shrinkage during pyrolysis of thin films and bulk components: The case of a hybrid silica gel precursor for SiOC glasses. J. Eur. Ceram. Soc. 2012, 32, 627-632. [CrossRef]

53. Olejniczak, Z.; Łęczka, M.; Cholewa-Kowalska, K.; Wojtach, K.; Rokita, M.; Mozgawa, W. 29Si MAS NMR and FTIR study of inorganic-organic hybrid gels. J. Mol. Struct. 2005, 744-747, 465-471. [CrossRef]

54. Zhang, H.; Pantano, C.G. Synthesis and Characterization of Silicon Oxycarbide Glasses. J. Am. Ceram. Soc. 1990, 73, 958-963. [CrossRef]

55. Reschke, V.; Bordia, R.K.; Scheffler, F.; Scheffler, M. Rheology and crosslinking of a low-viscosity SiOC preceramic polymer. Ceram. Int. 2016, 42, 7620-7625. [CrossRef]

56. Trimmel, G.; Badheka, R.; Babonneau, F.; Latournerie, J.; Dempsey, P.; Bahloul-Houlier, D.; Parmentier, J.; Soraru, G.D. Solid State NMR and TG/MS Study on the Transformation of Methyl Groups During Pyrolysis of Preceramic Precursors to SiOC Glasses. J. Sol. Gel Sci. Technol. 2003, 26, 279-283. [CrossRef] 
57. Pauletti, A.; Moskowitz, G.; Millan, T.; Fernández-Martín, C.; Boissière, C.; Gervais, C.; Babonneau, F. Aerosol-generated mesoporous silicon oxycarbide particles. Pure Appl. Chem. 2009, 81, 1449-1457. [CrossRef]

58. Gualandris, V.; Babonneau, F.; Janicke, M.T.; Chmelka, B.F. NMR Studies on Hydrolysis and Condensation Reactions of Alkoxysilanes Containing Si-H Bonds. J. Sol. Gel Sci. Technol. 1998, 13, 75-80. [CrossRef]

59. Bréquel, H.; Parmentier, J.; Walter, S.; Badheka, R.; Trimmel, G.; Masse, S.; Latournerie, J.; Dempsey, P.; Turquat, C.; DesmartinChomel, A.; et al. Systematic Structural Characterization of the High-Temperature Behavior of Nearly Stoichiometric Silicon Oxycarbide Glasses. Chem. Mater. 2004, 16, 2585-2598. [CrossRef]

60. Widgeon, S.J.; Sen, S.; Mera, G.; Ionescu, E.; Riedel, R.; Navrotsky, A. ${ }^{29}$ Si and ${ }^{13}$ C Solid-State NMR Spectroscopic Study of Nanometer-Scale Structure and Mass Fractal Characteristics of Amorphous Polymer Derived Silicon Oxycarbide Ceramics. Chem. Mater. 2010, 22, 6221-6228. [CrossRef] 